\title{
OBSERVATION OF INTERSPECIFIC COURTSHIP FEEDING BETWEEN A CLARK'S AND A WESTERN GREBE
}

ANDRÉ KONTER, National Museum of Natural History, 25 rue Münster L-2160 Luxembourg

e-mail: podiceps@pt.lu

\section{Abstract}

Two observations of Interspecific feeding classified as courtship feeding between a Clark's (Aechmophorus clarkii) and a Western Grebe (A. occidentalis) are reported. Due to the reproductive isolation between Western and Clark's Grebes, Interspecific feeding between both Aechmophorus species may be uncommon. But in regions of largely allopatric distribution, for instance in Canada, its occurrence could be more frequent.

\section{Introduction}

Mate feeding, the delivery of a food item to a possible breeding partner, is widespread in grebes. ${ }^{1}$ It is well known in Aechmophorus grebes where it is frequent just prior to nest-building. ${ }^{2}$ Food delivery has also been reported from wintering Western Grebes $(A$. occidentalis). ${ }^{3}$ Occasional partner feeding in the context of courtship has been observed in other grebe species, for instance in Little (Tachybaptus ruficollis), ${ }^{4}$ Great Crested (Podiceps cristatus), ${ }^{5}$ White-tufted (Rollandia microptera) ${ }^{1}$ and Red-necked Grebes ( $P$. grisegena, pers. observations). According to Nuechterlein and Storer, ${ }^{2}$ Western and Clark's Grebes (A. clarkii) have a short period of intensive mate-feeding behavior immediately preceding nest-building and egg laying. Mate-feeding is not part of the early pair formation rituals. Instead, it occurs during the pair-liaison period during which pair bonds are conspicuous and mates usually remain close together.

I here report of two observations that do not conform to the above contextual premises of Nuechterlein and Storer ${ }^{2}$ and that involved both Aechmophorus species, food having been delivered twice by a Clark's Grebe to a Western Grebe. Recognized only as separate species by the A.O. $U^{6}$ in 1985 , the genetic differentiation between both is not well established. $7,8,9,10,11,12,13$ Hybridization nevertheless seems to be rare and below $1 \%$ even in areas of largely sympatric occurrence, ${ }^{14,15,16,17}$ but may have increased more recently. ${ }^{18,19}$

\section{Place Of The Observations And Circumstances}

The observations were recorded from the shore at the Salmon Arm's Bay of Shuswap Lake, British Columbia, in the afternoon of 6 July 2012. Record high water levels had so far prevented Aechmophorus grebes from nesting in that season. From over 100 grebes present earlier only about 20 Western Grebes and a single Clark's Grebe were still present inside the bay. The observations were eased by Zeiss 10x25 binoculars and a Sigma $800 \mathrm{~mm}$ lens mounted on a tripod. The Clark's Grebe was initially as close as $20 \mathrm{~m}$ to the shore. When meeting the Western Grebe for the first feeding, he may have moved about $40 \mathrm{~m}$ further out. For the second food delivery, the distance to the shore had increased by another $30 \mathrm{~m}$. In the field, both Aechmophorus species are easily distinguished by the extent of white in their facial pattern: in Clark's Grebes, the white of the face extends to well above the eye whereas in Western Grebe the black crown comes down to well below the eye. In addition, Clark's Grebes have orangeyellow bills, those of Western Grebes are yellow-green. ${ }^{17,18}$ 


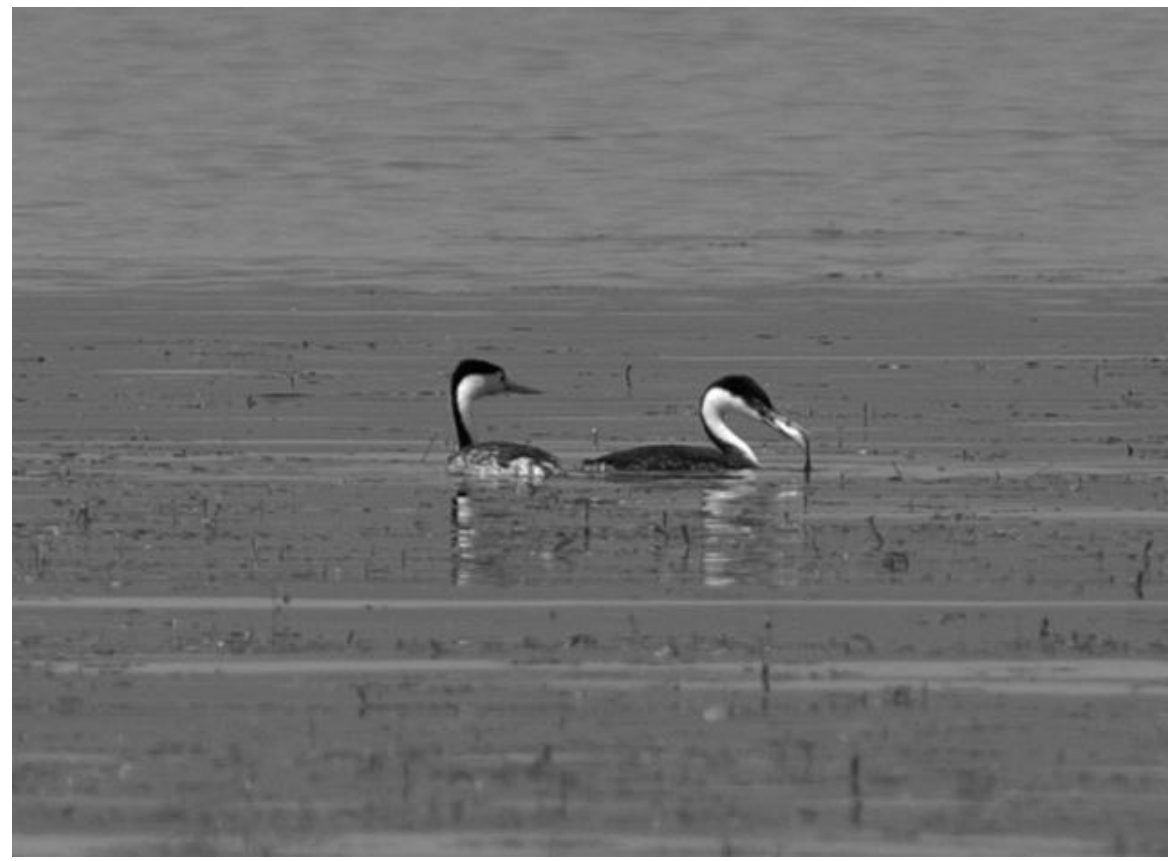

Figure 1. Western Grebe (with black crest reaching to below the eye) about to swallow the fish delivered by the Clark's Grebe (with white of the face extending to well above the eye).

\section{The Observations}

In a shallow corner to the east of the marina, the single Clark's Grebe and a single Western Grebe were diving for food at maximum distances from one another of about $20 \mathrm{~m}$. Two or three single Western Grebes and two pairs were scattered $150-200 \mathrm{~m}$ farther out; they were mostly loafing.

When the Clark's Grebe surfaced with a fish about $10 \mathrm{~cm}$ in length, it first handled it for a while in its beak so as preparing its swallowing. But then the grebe firmly locked the fish in between its mandibles, elevated its head and started calling. The Western Grebe in its vicinity showed no reaction. Having received no answer after several bouts of calling, the Clark's Grebe started to swim to and fro and repeated the calling. After some two or three minutes, a Western Grebe from farther out started to slowly swim in the direction of the Clark's Grebe. When the latter noticed this, it increased its swimming speed targeting the Western Grebe. This one at first continued its slow and apparently hesitant swimming before stopping its progression still at some $30 \mathrm{~m}$ from the Clark's Grebe. This grebe continued until both grebes met. The Clark's Grebe offered the fish to the Western Grebe who without displaying any begging behavior and after insistence by the donor accepted the gift and swallowed it (Figure 1). Both grebes now seemed to remain together for loafing, but quickly the Clark's Grebe resumed calling. However, the Western Grebe showed no interest in courtship activity and soon returned to the loose group from where it originated. The Clark's Grebe remained in place for a minute before it also left and resumed diving in the shallow corner.

It first caught a smaller fish that it swallowed quickly itself before again 
surfacing with another bigger fish. After handling it for perhaps 30 seconds, the fish was firmly trapped in the beak and the Clark's Grebe re-initiated its calling. Again, there was no immediate reply, neither by the Western Grebe that was still present in the corner nor by any other grebe farther out. The Clark's Grebe began swimming slowly into the direction of the scattered group of grebes, continuing the calling on its way and stopping now and then to survey the surroundings. The Western Grebe from before did not move in its direction. After having covered over $100 \mathrm{~m}$, the Clark's Grebe finally came close to a Western Grebe to which it offered its gift. It was presumably the same that had profited from the first fish. Only reluctantly the Western Grebe accepted the delivery, swallowed it, stayed close for less than one minute and then swam away. The calling of the Clark's Grebe could not make it stay and a few minutes later, the Clark's Grebe had again returned to the corner.

\section{Discussion}

The present observations of food delivery were peculiar in as far as they appeared not necessarily to involve two birds with an established liaison and they were interspecific.

In Aechmophorus grebes, according to Nuechterlein and Storer, ${ }^{2}$ feeding of a conspecific does not occur in early courtship, but only after firm pair liaisons are established. The term "mate-feeding" was chosen because food delivery then may become regular and potentially provide a significant direct energy contribution by males to egg formation. Although the observation of Salmon Arm occurred rather late in the season, the Clark's Grebe involved did not appear to have a pair liaison with the Western Grebe that received the fish and so far no nest-establishment efforts were recorded for the season. Mate feeding as defined by Nuechterlein and Storer ${ }^{2}$ and serving the energy needs of the female for egg formation therefore appears unlikely.

Also extra-pair feeding as reported by Forbes ${ }^{20}$ whereby unpaired male Western Grebes provide food to paired females tending young can be excluded, no young having been produced for the season. Forbes ${ }^{6}$ saw two possible reasons for the behavior: (1) the unpaired bird could be related to one of both parent birds and increase its inclusive fitness by enhancing the survival chances of the chicks in the brood, (2) the unpaired male could be attempting to procure a mate. James $^{3}$ observed feeding of conspecifics in wintering Western Grebes: in several pairs this was not occasional, but the female could be provisioned with several fish within a short period of time. While discarding the possibility that the behavior could be aberrant, James suggested that the feeding helped the formation of new or the maintenance of existing pairs and/or could be used by the females to assess male parental quality. Contextual evidence of the observations at Salmon Arm rather speaks in favor of an attempt of mate procurement or courtship feeding. Previous reports of food delivery by male Aechmophorus grebes did not mention interspecific feeding as was the case in Salmon Arm. Such observations may be generally rare as a consequence of the reproductive isolation between Western and Clark's Grebes. Differences in their advertising calls are to prevent both species from forming mixed pairs. Only in regions with largely allopatric distribution males show poor discrimination. ${ }^{14}$ Also late-courting males may be less choosy as with the progress of the season mating opportunities diminish. ${ }^{16}$ In this sense, the Salmon Arm Bay population and Canadian populations of Aechmophorus grebes more generally, including those of the prairie states, could be particularly auspicious to the observation 
of interspecific feeding. Clark's Grebes being generally rare in Canada, ${ }^{16,21,22}$ they often have no choice but to pair with a Western Grebe. In Salmon Arm, the first documented presence of a Clark's Grebe dates back to 1987 . Since then, there have been regular annual sightings of single male birds that at least occasionally appear to have interbred with Western Grebe females. ${ }^{23}$

In conclusion, interspecific feeding between Clark's and Western Grebes may occasionally occur and Canadian populations from British Columbia to Manitoba may present the most favorable conditions for the observation of the three different kinds of food delivery in Aechmophorus grebes, namely courtship feeding, ${ }^{3}$ mate feeding ${ }^{2}$ and extra-pair feeding. ${ }^{20}$

1. Fjeldså J (1985) Displays of the two primitive grebes Rollandia rolland and Rollandia microptera and the origin of the complex courtship behaviour of the Podiceps species (Aves:

Podicipedidae). Steenstrupia 11:133155.

2. Nuechterlein GL, Storer RW (1989) Mate feeding by Western and Clark's Grebes. The Condor 91:37-42.

3. James RA (1989) Mate feeding in wintering Western Grebes. Journal of Field Ornithology 60:358-360.

4. Bandorf H (1970) Der Zwergtaucher. Neue Brehm-Bücherei, A. ZiemsenVerlag Wittenberg Lutherstadt.

5. Bignal CE (1954) Courtship feeding in the Great Crested Grebe. British Birds 47:23.

6. American Ornithologists' Union (1985) Thirty-fifth supplement to the American Ornithologists Union checklist of North American birds. Auk 102:680-686.

7. Ahlquist JE, Bledsoe AH, Ratti
JT, Sibley CG (1987) Divergence of the single copy DNA sequences of the Western Grebe (Aechmophorus occidentalis) and Clark's Grebe ( $A$. clarkii), as indicated by DNA-DNA hybridization. Postilla 200:1-7.

8. Bledsoe AH, Sheldon FH (1989) The metric properties of DNA-DNA hybridization dissimilarity measures. Systematic Zoology 38:93-105.

9. Guerra R, Speed TP (1996)

Statistical issues arising in the analysis of DNA-DNA hybridization data. Systematic Biology 45:586-595.

10. Hebert PDN, Ratnasingham S, de Ward JR (2003) Barcoding animal life: cytochrome $c$ oxidase subunit 1 divergences among closely related species. Proceedings of the Royal Society of London, Series B 270:313321

11. Kerr KCR, Stoeckle MY, Dove CJ, Weigt LA, Francis CM, Hebert PDN (2007) Comprehensive DNA barcode coverage of North American birds. Molecular Ecology Notes, doi: 10.1111/j.1471-8286.2006.01670.x

12. Ratnasingham $S$, Hebert PDN (2007) BOLD: The Barcode of Life Data System (www.barcodinglife.org). Molecular Ecology Notes 7:355-364.

13. Savolainen V, Cowan RS, Vogler AP, Roderick GK, Lane R ( 2005) Towards writing the encyclopedia of life: an introduction to DNA barcoding. Philosophical Transactions of the Royal Society of London, Series B 360:18051811.

14. Nuechterlein GL (1981) Courtship behavior and reproductive isolation between Western Grebe color morphs. Auk 98:335-349.

15. Nuechterlein GL (1981) Variation and multiple functions of the advertising display of Western Grebes. Behaviour 76:289-317. 
16. Nuechterlein GL, Buitron DP (1998) Interspecific mate choice by late-courting male Western Grebes. Behavioral Ecology 9:313-321.

17. Ratti JT (1979) Reproductive separation and isolating mechanisms between sympatric dark- and lightphase Western Grebes.Auk 96:573-586

18. Konter A (2011) Interbreeding of Aechmophorus grebes. Wilson Journal of Ornithology 123:132-136.

19. Konter A (2012) Visual assessment of interbreeding by Aechmophorus grebes. Wilson Journal of Ornithology 124:711-718

20. Forbes L S (1985) Extra-pair feeding in Western Grebes. The Wilson Bulletin 97:122-123.
21. Eichhorst BA, Parkin BD (1991) Clark's Grebes and suspected Western $x$ Clark's Grebe hybrids in Manitoba. Blue Jay 49:196-200.

22. Konter A. (2009) Occurrence of Clark's Grebes and their hybrids with Western Grebes in Prairie Canada. Blue Jay 67:26-33.

23. Kime F, Kime D (2000) The Western Grebe and Clark's Grebe in the Salmon Arm bay of the Shuswap Lake from the years 1990-2000. Salmon Arm Bay Nature Enhancement Society.

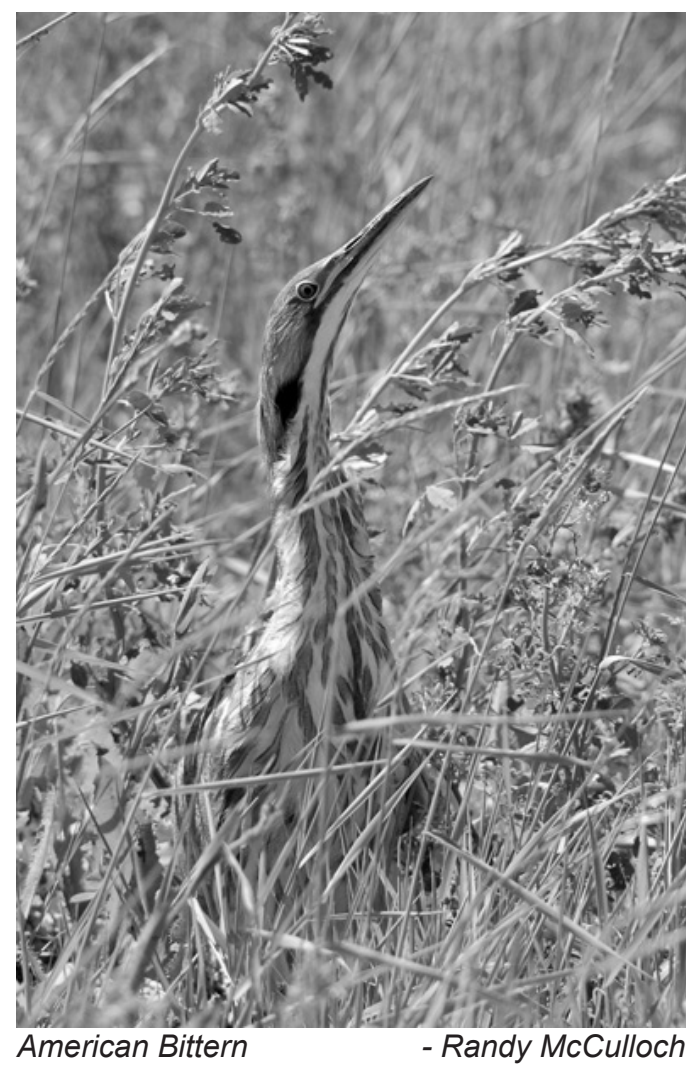

